Methods: We included all patients $(n=325)$ presenting to us from age 16 years with acute history ( $<7$ days) of fever with joints pain. They were assessed for demographic characteristics, pattern of joints involvement, systemic manifestations, lab parameters, and chikungunya virus positivity. All these parameters were observed according to age and sex and both clinical as well as laboratory markers were studied. We excluded 29 patients, twenty one had past history of inflammatory joint pain and rest had positive virology for dengue virus.

Results: We included 325 patients in which Males(M) were 140 and Females(F) were 185, F:M ratio of 1:0.75). The distribution of patients according to age was quite similar across all age groups. Small joints involvement in total of 287 patients (M:40.4\%,F:59.6\%), axial involvement in 219 patients (M:36.1\% and $F: 67.6 \%$ ), knee joint involvement in 285 patients (M:41.1\% and F:58.9\%), ankle pain in 285 patients(M:42.8\% and F:57.2\%), early morning stiffness was seen in 308 patients (M:44.8\% and $F: 55.19 \%)$, eyes involvement in 53 patients (M:35.8\% and $\mathrm{F}: 64.2 \%$ ), Neurological manifestations in 134 patients (M:43.3\% and $F: 56.7 \%$ ), stomatitis and oral ulcers in 85 patients (M:45.9\% and $F: 54.1 \%$ ), retrobulbar pain occurred in 73 patients (M:45.2\% and $\mathrm{F}: 54.8 \%$ ), rashes were seen in 47 patients (M:59.6\% and F:40.4\%). Forty two patients(12.9\%) had history of Diabetes ( $\mathrm{F}: 73 \%$ and $\mathrm{M}: 26 \%$ ) and 31 patients(9.5\%) were hypothyroid with female predominant $(100 \%)$. Urea and creatinine was also raised $(n=18)$. Rheumatoid factor was positive in 19 patients (M:42.1\% and $\mathrm{F}: 57.9 \%$ ). IgM Chikungunya was positive in 202 patients (M:46.04\% and $F: 53.96 \%$ ), and out of those 65 patients in which it was negative, we did RT-PCR in 18 patients due to unaffordability being a major factor and we found that RT-PCR came out positive in 15 patients. The mean ESR in males was $41.76 \pm 19.98$, in females it was $53.66 \pm 24.66$, mean CRP in males was $29.84 \pm 19.61$ and in females it was $40.74 \pm 25.94$.

Conclusions: We conclude that Chikungunya is a multisystem disease affecting both genders. In our setup, we observed it affected females more and seropositivity for chikungunya was seen in around half of the patients presenting with signs and symptoms. PCR test is more reliable for confirmation. Skin rashes with neurological symptoms, severe pain causing disability and dependence on others for personal care were main complaints. No mortality was reported in our study.

Disclosure of Interest: None declared

DOI: 10.1136/annrheumdis-2018-eular.1482

\section{SAT0391 MUSCULOSKELETAL MANIFESTATIONS OF CHIKUNGUNYA FEVER IN ELDERLY PATIENTS - CHIKBRASIL COHORT}

A. Dantas ${ }^{1}$, A. Duarte ${ }^{1}$, C. Marques ${ }^{1}$, A. Ranzolin ${ }^{1}$, N. Cavalcanti ${ }^{1}$, M. Medeiros ${ }^{2}$, M. Bezerra ${ }^{2}$, V. Marques ${ }^{2}$, L. Rocha Jr ${ }^{3}$, P. Melo ${ }^{3}$, L. Valadares $^{4}$, C. da Fonte ${ }^{4}$, E. Freire ${ }^{5}$, A.K. Melo ${ }^{5}$, R.A. Ocea ${ }^{6}{ }^{1}$ Internal Medicine, Universidade Federal de Pernambuco, Recife; ${ }^{2}$ Rheumatology, Universidade Federal do Ceará, Fortaleza; ${ }^{3}$ Internal Medicine, Instituto de Medicina Integral Professor Fernando Figueira IMIP; ${ }^{4}$ Internal Medicine, Hospital Getulio Vargas, Recife; ${ }^{5}$ Internal Medicine, Universidade Federal da Paraíba, João Pessoa; ${ }^{6}$ Internal Medicine, Universidade Federal de Sergipe, Aracaju, Brazil

Background: Elderly patients with Chikungunya virus (CHIKV) infection may exhibit atypical and more severe clinical manifestations in the acute phase $\left(,{ }^{1}\right.$ but little is known about these patients progress in the chronic phase of the disease. Objectives: To describe the chronic clinical course of CHIKV infection in Brazilian elderly patients.

Methods: The CHIKBRAZIL is a prospective, multicenter, observational cohort, conducted in six research rheumatology centres from the Northeast of Brazil, and has enrolled CHIK patients with joint manifestations since April 2016. ${ }^{2}$ Data from 353 patients followed up to December 2017 were analysed, divided into two groups: the elderly (age $\geq 60$ years) and not elderly.

Results: Of the 353 cases, 124 were elderly (35,1\%), mean age was 67.1 years $( \pm 5.6), 81.5 \%$ women. Patients in the elderly group had a higher frequency of comorbidities, such as systemic arterial hypertension $(p<0.0001)$, diabetes mellitus $(p<0.001)$ and hyperlipidemia $(p=0.0003)$. The median time of disease was 26 weeks, most of them were in the chronic phase of the disease $(61.3 \%)$. With respect to initial clinical manifestations, no significant differences were observed between the groups, except for fatigue, which occurred more often in the non-elderly group $(p=0.036)$. In general, the elderly group presented a lower frequency of absence at work (0.000), lower limb oedema (0.006) and less prescription of methotrexate $(p=0.048)$. In addition, it was also observed that older patients had a lower mean of the number of painful joints $(10.2 \pm 1.7)$, but without statistical difference $(p=0.0655)$. After a median follow-up time of 27.5 weeks, the number of patients who presented complete improvement was higher in the non-elderly group ( $p=0.07$ ), but without differences between the number of tender and swollen joints, persistence of arthralgia or arthritis in the two groups. No association was observed between the presence of comorbidities and the clinical evolution of the patients.

Conclusions: Despite the risk of a more severe evolution at the onset of CHIKV infection, elderly patients present a similar clinical course to the non-elderly in the chronic phase, apparently with less severity. However, such group is a high-risk population with an important number of comorbidities. In all stages of the disease, especially in the acute phase, strict clinical supervision is recommended regarding the use of drugs and increased risk of complications.

\section{REFERENCES:}

[1] Chopra A, Anuradha V, Ghorpade R, Saluja M. Acute Chikungunya and persistent musculoskeletal pain following the 2006 Indian epidemic: a 2year prospective rural community study. Epidemiol Infect 2012;140(5):84250 .

[2] Marques CDL, Cavalcanti N, Luna M, et al. Chikungunya Fever Outbreak in Brazil: Preliminary Assessment in a Cohort of Patients with Rheumatological Manifestations. Arthritis Rheumatol [Internet] 2016 20-nov-2016;68 (S10).

Disclosure of Interest: None declared

DOI: 10.1136/annrheumdis-2018-eular.7458

\section{SAT0392 THE RELEVANCE OF SERUM PROCALCITONIN QUANTIFICATION FOR DIFFERENTIAL DIAGNOSIS OF INFECTIONS AND RHEUMATIC DISEASES}

A. Dilbaryan, B. Belov, G. Tarasova, D. Bukhanova. V.A. Nasonova Research Institute of Rheumatology, Moscow, Russian Federation

Background: Assessment of procalcitonin (PCT) serum levels is of great interest in current rheumatology practice, due to clinical and laboratory similarity of acute systemic rheumatic diseases (RDs) and acute infectious process, and because of low diagnostic yield of conventional ESR, CRP and WBC in active RDs.

Objectives: To evaluate the relevance of PCT as a specific marker of generalised and local infections in patients with RDs.

Methods: Medical records of 134 in-hospital patients (mean age 40,6 $\pm 19,5$ ) admitted to VA Nasonova Research Institute of Rheumatology for examination and treatment were analysed in this retrospective study. Serum PCT concentration was measured using quantitative electrochemiluminescence method, Cobas E 411 analyzer (Roshe, Switzerland). The infectious process was diagnosed in 75 pts, generalised - in 4, and local - in 71. Based on the severity of fever and intoxication local infections were divided into mild -41 cases, and severe -30 cases.

Results: The PCT level reached $>2.0 \mathrm{ng} / \mathrm{mL}$ in 3 of 4 cases in generalised infection. In population with severe local infections $(n=30)$ the PCT concentration exceeded the threshold and amounted to $0.60 \mathrm{ng} / \mathrm{mL}[0.19 ; 1,84]$, while in pts with mild infection $(n=41)$ it was $0.13 n g / m L ~[0,08 ; 0,25]$ (table 1). PCT levels positively correlated with ESR, CRP, white blood cell count, and SLE activity according to SLEDAI index in this retrospective study. Maximal PCT levels were found in adultonset Still's disease (ASD) pts with high activity of rheumatic process without underlying infection $-0.26[0.10 ; 0,61] \mathrm{ng} / \mathrm{mL}$. The test's sensitivity and specificity in generalised/severe local infections group $(n=34)$ were $60 \%$ and $82,5 \%$, respectively, with a threshold value of $0.4 \mathrm{ng} / \mathrm{mL}$.

Abstract SAT0392 - Table 1. PCT values in different groups of patients, $n$ (\%)

\begin{tabular}{|c|c|c|c|c|c|}
\hline \multirow[t]{2}{*}{ РCT level, ng/mL } & \multirow{2}{*}{$\begin{array}{c}\text { Generalised } \\
\text { infection }(n=4)\end{array}$} & \multicolumn{2}{|c|}{ Local infection } & \multicolumn{2}{|c|}{ No infection } \\
\hline & & $\begin{array}{l}\text { Severe } \\
(n=30)\end{array}$ & $\begin{array}{c}\text { Mild } \\
(n=41)\end{array}$ & $\begin{array}{c}\text { Still's } \\
\text { disease } \\
(n=6)\end{array}$ & $\begin{array}{l}\text { Totally } \\
(n=59)\end{array}$ \\
\hline$\leqslant 0,05$ & - & $1(1,33)$ & $4(9,76)$ & - & $12(20,34)$ \\
\hline $0,05-0,1$ & - & $2(6,67)$ & $13(31,71)$ & $1(16,67)$ & $19(32,20)$ \\
\hline $0,1-0,25$ & - & $5(16,67)$ & $13(31,71)$ & $2(33,33)$ & $16(27,12)$ \\
\hline $0,25-0,5$ & $1(25)$ & $6(20,0)$ & $6(14,63)$ & $1(16,67)$ & $6(10,17)$ \\
\hline $0,5-2,0$ & 0 & $11(36,67)$ & $5(12,20)$ & $2(33,33)$ & $6(10,17)$ \\
\hline $2,0-10,0$ & $1(25)$ & $3(10,0)$ & - & - & - \\
\hline$>10.0$ & $2(50)$ & $2(6.67)$ & - & - & - \\
\hline $\begin{array}{l}\text { Me [25-й; 75-й } \\
\text { percentiles] }\end{array}$ & $5,30^{1,63 ; 9,06^{*}}$ & $\begin{array}{c}0,60[0,19 ; \\
1,84]^{*}\end{array}$ & $\begin{array}{c}0,13[0,08 \\
0,25]^{*}\end{array}$ & $\begin{array}{c}0,26 \\
{[0,10 ; 0,61]}\end{array}$ * & $\begin{array}{c}0,09[0,06 ; \\
0,19]^{\star}\end{array}$ \\
\hline
\end{tabular}

Conclusions: PCT quantification is a sensitive and specific method for differen tial diagnosis of serious bacterial infections in patients with different activity of sys temic RD. ASD seems to be the exception, as it was associated with PCT increase in the absence any infection. Further studies are needed to determine PCT thresholds for different RDs.

Disclosure of Interest: None declared

DOI: 10.1136/annrheumdis-2018-eular.2020 